\title{
Size-related and seasonal changes in the diet of the non-native Cichla kelberi Kullander \& Ferreira, 2006 in a lowland reservoir in the southeastern Brazil
}

\author{
Helaine Silva Mendonça ${ }^{1,2 *}$, Alexandre Clistenes Alcântara Santos ${ }^{2}$, Mariana Marques Martins ${ }^{I}$ \\ \& Francisco Gerson Araújo ${ }^{I}$ \\ ${ }^{1}$ Universidade Federal Rural do Rio de Janeiro, Rodovia BR 465, Km 07, Campus Universitário, 23890-000, \\ Seropédica, RJ, Brasil \\ ${ }^{2}$ Universidade Estadual de Feira de Santana, Departamento de Ciências Biológicas, Av. Universitária s $/ n$, \\ Novo Horizonte, 44036-900, Feira de Santana, BA, Brasil \\ *Corresponding author: Helaine Mendonça, e-mail: helainemendonca26@gmail.com
}

MENDONÇA, H. S.; SANTOS, A. C. A.; MARTINS, M. M.; ARAÚJO, F. G. Size-related and seasonal changes in the diet of the non-native Cichla kelberi Kullander \& Ferreira, 2006 in a lowland reservoir in the southeastern Brazil. Biota Neotropica. 18(3): e20170493. http://dx.doi.org/10.1590/1676-0611-BN-2017-0493

\begin{abstract}
We examined size-related and seasonal changes in the diet of the peacock bass Cichla kelberi in a tropical lowland reservoir in southeastern Brazil over three hydro-climatic seasons: summer (high rainfall and temperature), winter (low rainfall and temperature), and late spring (increasing rainfall and temperature) during two years (20062007). The tested hypothesis is that this non-native predator fish changes diet during the subadult and adult phases and among seasons to adapt in new colonized environment. Fishes of the families Clupeidae (Platanichthys platana), Characidae (Astyanax spp.) and Cichlidae (Cichla kelberi) were the most important food items, followed by insects of the order Odonata. Cannibalism was also recorded for the largest individuals. A significant size-related change in diet was found with the smallest individuals (Total Length, $\mathrm{TL}<20 \mathrm{~cm}$ ) preying mainly on fishes, whereas the larger individuals ( $\mathrm{TL}>30 \mathrm{~cm}$ ) preyed mainly on Odonata. The niche breadth increased during growth, with the largest individuals having a diet more evenly distributed among the available resources. No significant seasonal differences in diet composition were found, but stomachs with higher degree of volume occupied by food were more frequent in late spring than in summer. Conversely, the highest niche breadth was found during the summer compared to the other seasons. Together, these observations suggest an efficient use of the available resources by this top predator in this new colonized system.
\end{abstract}

Keywords: Feeding ecology, freshwater fishes, non-native species, piscivory, impoundment.

\section{Mudanças sazonais e relacionadas ao tamanho da dieta do não-nativo Cichla kelberi \\ Kullander \& Ferreira, 2006 em um reservatório de planície no sudeste do Brasil}

\begin{abstract}
Resumo: Foram examinadas as mudanças sazonais na dieta e relacionadas ao tamanho para o tucunaré Cichla kelberi em um reservatório tropical de várzeas no Sudeste do Brasil em três ciclos hidrológicos: verão (elevadas precipitações e temperaturas), inverno (baixas precipitações e temperaturas), e final da primavera (aumentos das precipitações e temperaturas) durante dois anos (2006-2007). A hipótese testada é que este peixe predador não-nativo muda a dieta durante as fases adulta e subadulta e entre as estações do ano para se adaptar neste novo ambiente colonizado. Peixes das famílias Clupeidae (Platanichthys platana), (Characidae (Astyanax spp.) e Cichlidae (Cichla kelberi) foram os itens alimentares mais importantes, seguidos por insetos da ordem Odonata. O canibalismo também foi registrado para os maiores indivíduos. Mudanças significativas na dieta foram relacionadas ao tamanho, com os indivíduos menores (Comprimento Total, CT $<20 \mathrm{~cm}$ ) utilizando principalmente peixes, enquanto os indivíduos maiores $(\mathrm{CT}>20 \mathrm{~cm}$ ) se alimentaram principalmente de Odonata. A amplitude de nicho aumentou ao longo do crescimento, com indivíduos de maior porte tendo dieta mais uniformemente distribuída entre os recursos disponíveis. Nenhuma diferença significativa na composição da dieta foi encontrada entre as estações do ano, mas estômagos com maiores volumes ocupados pelo alimento foram mais frequentes no fim da primavera e menos frequentes no verão. Por outro lado, a maior amplitude de nicho foi encontrada no verão comparada com as outras estações, o que indica o uso mais uniforme dos diversos recursos disponíveis. Juntas, estas observações sugerem uma utilização eficiente dos recursos disponíveis por esta espécie predadora de topo neste novo sistema colonizado.
\end{abstract}

Palavras-chave: Ecologia alimentar, peixes de água doce, espécies não nativas, piscívora, represamento. 


\section{Introduction}

Many rivers in southeastern Brazil have undergone considerable changes due to the construction of dams. The artificial lakes fragment the lotic system, blocking routes for fish migration and forming systems with new environmental conditions (Agostinho et al. 2008). As a result, the natural structure of the fish assemblages changes in the new environment favoring the establishment of non-native fish species. The non-native species are, in many cases, more tolerant to the lentic conditions than the previously native lotic fish fauna (Hoeinghaus et al. 2009, Araújo et al. 2013).

Knowing the ecology of invasive species is crucial to help environmental managers in policies aiming the biodiversity conservation (Gozlan 2008). Trophic plasticity is a fundamental condition for species to adapt to a newly created lentic environment such as the reservoirs. Introduced species can affect the functioning of ecosystems by changing trophic relationships, besides presenting other deleterious effects (Adams 1991, Meffe et al. 1997, Marchetti 1999, Kati et al. 2015). These changes may have important economic and ecological consequences (Gomiero \& Braga 2003, Fugi et al. 2008, Pelicice \& Agostinho 2009). Native species may change their abundance due to competition with non-native species (Zaret \& Paine 1973, Lodge 1993, Khan \& Panikkar 2009, Kati et al. 2015). On the other hand, non-native species can alter the functioning of local ecosystems by intensifying predation pressure on native species, or by searching for other prey that are not used by native predators (Zavaleta et al. 2001, Laxson et al. 2003).

Cichla species have successfully invaded Neotropical reservoirs and this may seriously threaten native fish diversity due to their high predatory capacity (e.g., Santos et al. 2001, Latini \& Petrere, 2004, Novaes et al. 2004, Fugi et al. 2008. Pinto-Coelho et al. 2008, Kolavensko et al. 2010, Menezes et al. 2012, Pelicice et al. 2015). Species of Cichla are able to change their diets according to resources availability, usually related to seasonal and ontogenetic variations (Gomiero et al. 2010). Seasonal changes in the fish diet associated to changes in water temperature and photoperiod also influence food availability (Zavala-Camin 1996). Moreover, in environments where species of Cichla have been introduced, high cannibalism rates can occur (Santos et al. 1994, Durães et al. 2000, Gomiero \& Braga 2004b).

The peacock bass Cichla kelberi Kullander and Ferreira 2006 is native and endemic to the Araguaia and Tocantins Rivers basins (Kullander \& Ferreira 2006) but has been introduced in several aquatic systems across the country. This species has been introduced in Brazilian reservoirs since the 1950s by hydroelectric companies and by amateur anglers and has colonized large areas of river basins (Oliveira et al. 1986). The wide distribution and high abundance of C. kelberi in Brazilian reservoirs suggests a high impact on the native fish communities and other aquatic organisms (Magalhães et al. 1996, Câmara et al. 2002, Chellapa et al. 2003, Gomiero \& Braga 2003, Fugi et al. 2008, Santos et al. 2011, Pelicice et al. 2015). It is a top predator with piscivorous habits (Lowe McConnel 1969, Braga 1990, Arcifa \& Meschiatti 1993, Jepsen et al. 1997, Novaes et al. 2004, Pelicice \& Agostinho 2009, Montaña 2011), favored by its accurate visual capacity, preying largely on small fishes but occasionally consuming shrimps and other aquatic invertebrates when adults (Winemiller 2001, Kullander $\&$ Ferreira 2006, Santos et al. 2011). As most successful invaders, this species must be able to adapt to novel environmental conditions that include shifting feeding habits to explore the available resources. It is widely accepted that species of Cichla change diet during growth, with the juveniles feeding mainly on crustaceans and insects whereas the adults fed mainly on fishes (Gomiero \& Braga 2004a, Novaes et al. 2004).

Cichla kelberi was introduced in the Juturnaíba Reservoir, a tropical impoundment in the north of Rio de Janeiro State, shortly after the reservoir construction, about three decades ago. This study aimed to assess dietary preference of Cichla kelberi and eventual changes among seasons and size-classes in the Juturnaíba Reservoir. Knowing the diet of $C$. kelberi from gut analyses, although may reflect more on prey availability than preference towards a particular prey species, is one of the first step to assess their success in the new colonized system. We hypothesized that there are size-related and seasonal changes in the diet of Cichla kelberi in the Juturnaíba Reservoir, which may be a mechanism that favor the use of available resources.

\section{Material and Methods}

\section{Studied area}

The dam on the São João River that formed the Juturnaíba Reservoir ( $22^{\circ} 36^{\prime} \mathrm{S}, 42^{\circ} 16^{\prime} \mathrm{W}$ ) is located at $65 \mathrm{~km}$ from the river headwaters and $38.5 \mathrm{~km}$ from its mouth in the Atlantic Ocean (Fig. 1). The reservoir has approximately $30.6 \mathrm{~km}^{2}$ of water surface, a maximum depth of 9 meters and water volume of 100 million $\mathrm{m}^{3}$ (Afonso \& Cunha 1989). The reservoir has an average depth of 4 meters and is located in lowland areas of northeast floodplains of Rio de Janeiro State. We defined three instead of four seasons because changes in the major factors of temperature and rainfall reflect better three and not four seasonal periods: (i) summer, with the highest temperatures and rainfalls; (ii) winter, when environmental conditions are stable, characterized by the lowest temperature and rainfall; (iii) late spring, when the area experiences changes in environmental variables, with strong southwestern winds coinciding with increases in rainfall and temperature. Such seasons were already established in other studies (e.g. Azevedo et al. 2016) and the database supporting this pattern is available from the Instituto Nacional de Meteorologia (INMET), available at http://www.inmet.gov.br/html/clima.php\#.

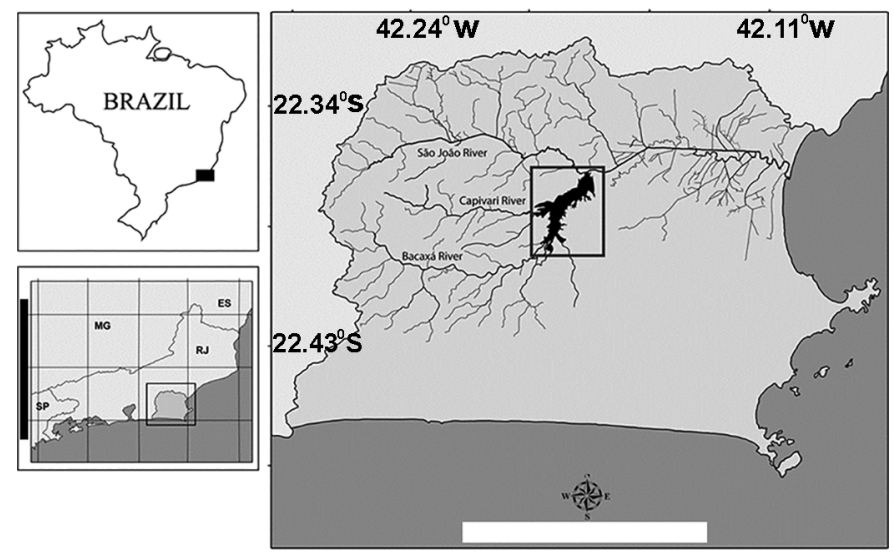

Figure 1. Map showing the study area, the Juturnaíba Reservoir and its drainage area, Rio de Janeiro, Brazil. 


\section{Sampling and data handling}

Fishes were sampled in March (summer), August (winter) and December (late spring) during two years (2006 and 2007), covering two full hydro-climatic cycles. Information from each year were pooled by seasons, with years being used as replications of the seasons. At each season and each year, excursions were carried out at 7 sites randomly chosen covering most area of the reservoir, totaling 42 samples (7 sites $\times 3$ seasons $\times 2$ years $)$. Seven gill nets $(30 \mathrm{~m}$ long $\times 3 \mathrm{~m} \mathrm{high})$ of different mesh size (2-7 cm stretched mesh) at each sampling site were used. The nets were set up at sunrise and retrieved the following afternoon, remaining in operation for ca. $20 \mathrm{~h}$. All fish were identified, measured for total length (TL, in centimeters) and weighed (in grams). The stomachs were removed and fixed in 10\% formalin, and after 48 hours transferred to $70 \%$ ethanol.

For each individual, the degree of fullness in the stomach (SF) was measured and classified according to the following categories: SF-0 (empty stomach), SF-1 ( $<30 \%$ of stomach volume occupied by food); SF-2 (between 30 and 70\%); and SF-3 (above 70\%).

The food items were identified under a stereomicroscope. Fish with empty stomachs or those with unidentifiable contents were excluded from the analyses. The volume of each identified food item was measured according to Albrecht \& Caramaschi (2003). The volume and the frequency of occurrence of the food items were used to calculate the Alimentary Index (AI) proposed by Kawakami \& Vazzoler (1980) according to the following equation: $\mathrm{IAi}=\% \mathrm{Fi} \times \% \mathrm{Vi} / \Sigma(\% \mathrm{Fi} \times \mathrm{Vi})$, where: $\mathrm{IAi}=$ Index Feeding; $\% \mathrm{Fi}=$ Frequency of occurrence of the item $\mathrm{i}$ in the diet $(\%) ; \mathrm{V}=$ Volume of the item $\mathrm{i}$ in the $\operatorname{diet}(\%)$.

\section{Data analyses}

The stomach contents of individuals were analyzed covering the three periods (March, August and December 2006 and 2007). To assess possible changes in diet with respect to size, fish were divided into three size classes that were assigned according to observed size ranges: Total Length (TL) TL1 $<20 \mathrm{~cm}$; TL2 $=20-30 \mathrm{~cm}$; TL3 $>30.0 \mathrm{~cm}$. Although these size classes do not encompass the juveniles ( $\mathrm{TL}<10 \mathrm{~cm}$, according to Novaes et al. 2004) at smaller lengths, they included the subadult and adult, which are the focus of the present study.

The volume of the food items for each sample was square root transformed and converted into a triangular matrix of similarities among all samples, using the Bray-Curtis similarity measure (Schafer et al. 2002). The diet composition was compared among seasons (three seasons) and size class (three size classes) that were the fixed factors. We used ANOSIM procedure at a significance level of $\mathrm{P}<0.05$ to compare the diet composition among seasons and size classes. Theses analyses were performed with the PRIMER software package version $6.0+$ PERMANOVA (Anderson et al. 2008). The volumetric data obtained for the food items were used to calculate the standardized Levin's index as a measure of the niche breadth for each season and size class.

\section{Results}

A total of 125 specimens of $C$. kelberi were examined from which 98 had stomachs with identifiable food items and 27 were empty. A total of 34 individuals were examined in summer, 38 in winter and 26 in late spring. The specimens examined had sizes ranging from 9.7 to $48.1 \mathrm{~cm}$
Total Length (TL), with 36 individuals in size class TL1 ( $<20 \mathrm{~cm} \mathrm{TL})$, 45 individuals in size class TL2 (20-30 cm TL) and 17 individuals in size class TL3 ( $>30 \mathrm{~cm} \mathrm{TL})$.

The diet consisted mainly of fishes and insects (Table 1). During the summer, the most important food items was fish remains (IAi $=36.15 \%$ ) and juveniles of Cichla kelberi (IAi $=22.39 \%$ ). During the winter, the most important food item was Odonata (IAi $=52.15 \%$ ) followed by characid fishes Astyanax spp. (IAi $=34.63 \%)$, whereas in the late spring, Odonata (IAi $=55.86 \%)$, followed by fish remains $(\mathrm{IAi}=24.19 \%)$ and the clupeid Platanichthys platana (Regan, 1917) $(\mathrm{IAi}=18.18 \%)$ were the main food items (Table 1). The Cichlidae family was represented by $C$. kelberi, indicating cannibalism habit. No significant seasonal differences were found in the diet composition $(\mathrm{R}$ global $=0.022 ; \mathrm{P}=$ 0.132 ) according to the ANOSIM test.

The frequency of stomachs with lower than $30 \%$ of fullness (SF-1) and with $30-70 \%$ of fullness (SF-2) was higher in late spring and lower in summer (Fig. 2). Conversely, the frequency of empty stomachs (SF-0) was higher in summer and lower in late spring. No seasonal differences were found in the frequency of stomachs with higher than $70 \%$ of fullness (SF-3).

The diet composition changed significantly $(\mathrm{R}$ global $=0.286 ; \mathrm{P}=$ 0.03 ) among the three size classes according to the ANOSIM (Fig. 3). The smallest individuals (TL1) fed mainly on fish remains and fishes from the family Clupeidae, whereas the medium-sized individuals (TL2) fed preferably on fish remains and Platanichthys platana. The largest individuals (TL3) fed on Odonata and fishes from the Characidae family. Cannibalism was recorded mainly in the largest individuals that fed mainly on juveniles of $C$. kelberi.

Niche breadth was low, with comparatively higher values in summer (0.35) and lower in winter (0.21) and late spring (0.14). There was a trend of increasing niche breadth as fish grew, with lower values $(0.12)$ in the sizes smaller than $20 \mathrm{~cm}$ (TL1), then increases to 0.21 in the $20-30 \mathrm{~cm}$ TL size class (TL2), reaching the highest value (0.24) at sizes larger than $30 \mathrm{~cm}$ (TL3).

\section{Discussion}

The non-native Cichla kelberi seems to adapt its trophic niche to use a broad spectrum of the available resources in the Juturnaíba Reservoir. It is noticeable its opportunist carnivore strategy by using 16 different food item, usually in high volume and in low frequency. A generalist trait favors successful invasions (Ribeiro et al. 2007, Brandner et al. 2013) since it is less affected by shifting prey availability, whereas a specialist feeding strategy could result in fluctuating population abundance of the predator when preferred prey abundance varies (Volterra 1928).

Specialization in piscivory as the main feeding habit for species of Cichla is widely known (e.g., Santos et al. 2001, Rabelo et al. 2002, Gomiero \& Braga 2004a, Novaes et al. 2004, Santos et al. 2004, VillaresJunior \& Gomiero 2010, Pereira et al. 2015). However, some degree of trophic plasticity is also described for these species, which prey occasionally on shrimps and other aquatic invertebrates (Winemiller et al. 2001, Kullander \& Ferreira 2006). Winemiller et al. (1997) found that Characiformes and Perciformes fishes are the major prey for species of Cichla, and food partitioning has been documented for C. temensis 
Mendonça, H.S. et al.

Table 1. Diet composition (\% of the Alimentary Index - IAi) of Cichla kelberi in the Juturnaíba Reservoir in the three seasons (summer, winter and late spring).

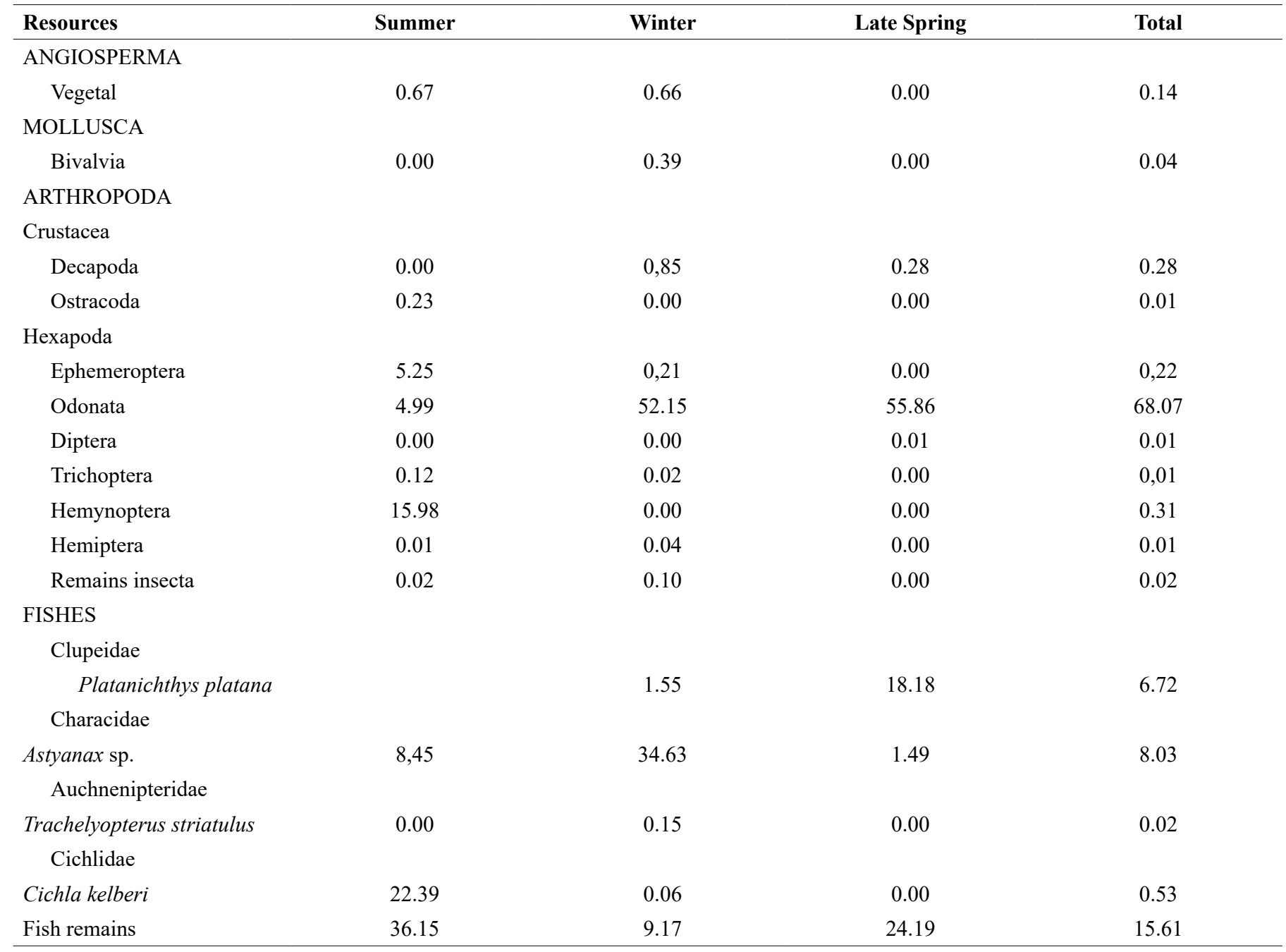

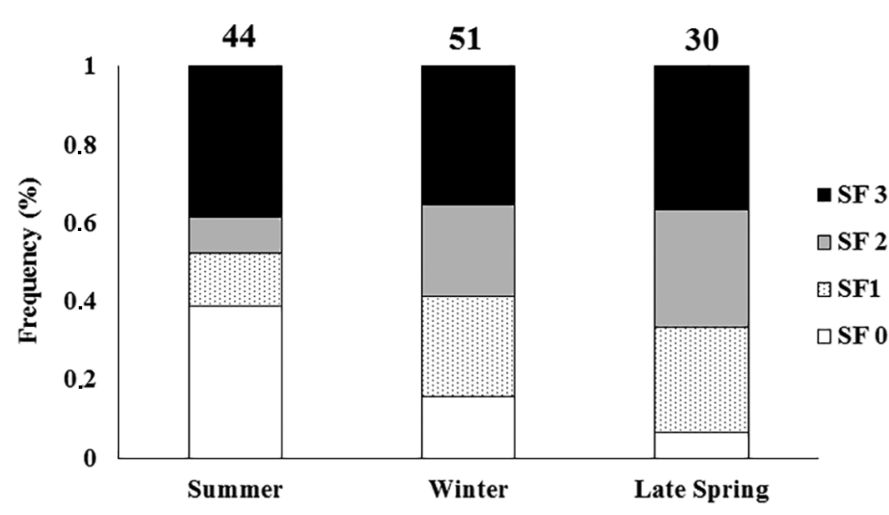

Figure 2. Frequency (\%) of stomach of Cichla kelberi in the Juturnaiba Reservoir in different fulness degrees. SF- 0 , empty stomachs; SF- $1,<30 \%$ of the stomachs volume occupied by food; SF-2, 30-70\%; SF-3, > 70\%. Numbers of examined individuals also indicated.

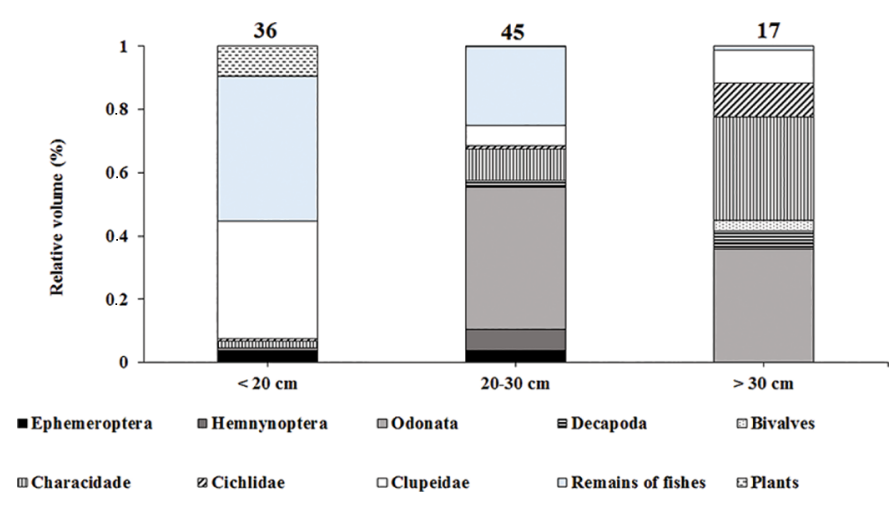

Figure 3. Main food items (\% volume) by size classes of Cichla kelberi in the Juturnaíba Reservoir. Numbers of individuals examined also indicated. 
and $C$. intermedia in the Cinaruco River, in Venezuela. In the Guri Reservoir, C. temensis feeds more on Characiforms and less on Cichlids than $C$. orinocensis. In the Tocantins River, the Tetragonopterinae subfamily was reported as the main prey for Cichla kelberi during the construction phase of a large reservoir (Serra da Mesa Reservoir), whereas the cichlids were the dominant prey during the operation phase (Novaes et al. 2004).

In its natural environment, the Tocantins-Araguaia watershed, Cichla kelberi preys mainly on small Tetragonopterinae, and to a lesser extent on shrimps and insects, besides practicing cannibalism (Novaes et al. 2004). When introduced in other reservoirs, this species prey on a variety of fish species that are available (Table 2), mainly small characiforms, siluriforms and cichlids, besides shrimps and insects (Santos et al. 2001, Gomieiro \& Braga 2004a, Santos et al. 2004, Villares Junior \& Gomiero 2010, Pereira et al. 2015). In the present study, this trend for using the available resources was confirmed, with $C$. kelberi preying mainly on characids, clupeids and cichlids. Additionally, a remarkable amount of insects of the order Odonata was also recorded in the stomachs examined.

Cannibalism is another aspect of the trophic behavior of Cichla species that is developed especially in invaded reservoirs. The high degree of cannibalism displayed by C. kelberi in the Corumbá (Fuji et al. 2008), Lajes (Santos et al. 2011) and Porto Primavera (Pereira et al. 2015) reservoirs highlights the aggressive behavior exhibited by this species. In the Lajes Reservoir, high cannibalism was recorded accounting for $50 \%$ of the diet (Santos et al. 2011). We found that cannibalism is higher in larger individuals of $C$. kelberi, as also reported in other reservoirs (Gomiero \& Braga 2004, Pereira et al. 2015). Cannibalism, although being recorded in the Juturnaíba Reservoir, does not seem to be the most important source of feeding for $C$. kelberi. During the summer, the spawning season increases the number of early juveniles, which are easily preyed by the adult individuals (Gomiero et al. 2009). In the present study, cannibalism was also more frequent in summer, when the fullness indexes were at the lowest levels.

A conspicuous change in the diet was found during the subadult and adult phase, with the smallest individuals preying on a limited number of resources, mainly fishes of the family Clupeidae, whereas the largest individuals increased their trophic breadth preying mainly on insect of the order Odonata and fishes of the family Characidae. During and after the parental care period, juveniles $(<10 \mathrm{~cm} \mathrm{TL})$ of Cichla spp feed themselves on zooplankton, such as cladocerans, copepods, and microcrustacea; above this length, the diet is based on crustaceans, insects, and small fishes, with fish being the preferential item for adults (Lowe-McConnell 1969, Santos et al. 1994, Jepsen et al. 1997, Winemiller 2001). We also found that the niche breadth increased with growth, because the largest adults $(>20 \mathrm{~cm}$ TL) consumed in an even proportion more items compared with the subadults $(<20 \mathrm{~cm}$ TL). This is the opposite to the pattern detected by Gomiero \& Braga (2004a) for species of Cichla in the Volta Grande Reservoir, where the smallest individuals had the largest niche breadth, feeding mainly on

Table 2. Main food items in decreasing importance used by $C$. kelberi in different aquatic systems.

\begin{tabular}{|c|c|c|c|}
\hline Aquatic system & Origin & Main food items & References \\
\hline $\begin{array}{l}\text { Porto Primavera Reservoir } \\
\text { (Southern Brazil), } \\
\text { Paraná river basin }\end{array}$ & Non-native & $\begin{array}{l}\text { Fishes (Anostomidae, Cheirodontidae, Curimatidae, Sternopygidae e } \\
\text { Cichlidae) and Crustacea (Decapoda) }\end{array}$ & Pereira et al. 2015 \\
\hline $\begin{array}{l}\text { Lajes Reservoir } \\
\text { (Southeastern Brazil) }\end{array}$ & Non-native & $\begin{array}{l}\text { Fishes (Cichlidae - Cichla kelberi, Crenicichla lacustris and Tilapia } \\
\text { rendalli, Characidae - Astyanax spp.; Oligosarcus hepsetus; Pimelodidae - } \\
\text { Pimelodella eigenmani and Rhamdia parahybae) Insects (Odonata - nymphs } \\
\text { and adults; Hemiptera); fish eggs; Crustacea (Macrobrachium sp.) and } \\
\text { unidentifield fishes. }\end{array}$ & Santos et al. 2011 \\
\hline $\begin{array}{l}\text { Leme Lake } \\
\text { (Southeastern Brazil) }\end{array}$ & Non-native & $\begin{array}{l}\text { Fishes (Cichlidae - Tilapia sp., C. kelberi and Geophagus brasiliensis; } \\
\text { Callichthyidae - Hoplosternum litoralle), Ophidia and unidentifield fishes }\end{array}$ & $\begin{array}{l}\text { Villares Junior \& } \\
\text { Gomiero } 2010\end{array}$ \\
\hline $\begin{array}{l}\text { Corumbá Reservoir, Rio } \\
\text { Grande, Paraná river basin }\end{array}$ & Non-native & $\begin{array}{l}\text { Fishes (Galeocharax knerii, Cichlasoma paranaense, Astyanax altiparanae, } \\
\text { Cichla kelberi and P. maculatus }\end{array}$ & Fugi et al. 2008 \\
\hline $\begin{array}{l}\text { Lajes Reservoir } \\
\text { (Southeastern Brazil) }\end{array}$ & Non-native & $\begin{array}{l}\text { Fishes (Cichlidae - Cichla monoculus, Crenicichla lacustris and Tilapia } \\
\text { rendalli, Characidae - Astyanax spp.; Oligosarcus hepsetus; Pimelodidae - } \\
\text { Pimelodella eigenmani and Rhamdia parahybae) Insects (Odonata - nymphs } \\
\text { and adults; Hemiptera); fish eggs; Crustacea (Macrobrachium sp.) and plants. }\end{array}$ & Santos et al. 2004 \\
\hline $\begin{array}{l}\text { Volta Grande Reservoir, } \\
\text { (Southeastern Brazil), } \\
\text { Paraná river basin }\end{array}$ & Non-native & $\begin{array}{l}\text { Fishes (Cichlidae - Cichla sp., Tilapia rendali and Scianidae - Plagioscion } \\
\text { squamosissimus, fishes remains and others species), Insects (Culicidae, } \\
\text { Odonata) and Shrimp (Macrobrachium sp.) }\end{array}$ & $\begin{array}{l}\text { Gomiero \& Braga } \\
2004 a\end{array}$ \\
\hline $\begin{array}{l}\text { Serra da Mesa Reservoir } \\
\text { (Western Brazil), } \\
\text { Tocantins river basin }\end{array}$ & Native & Fishes (Tetragonopterinae, unidentifield fishes and Cichlidae), Insects. & $\begin{array}{l}\text { Novaes et al. } \\
2004\end{array}$ \\
\hline $\begin{array}{l}\text { Lajes Reservoir } \\
\text { (Southeastern Brazil) }\end{array}$ & Non-native & $\begin{array}{l}\text { Fishes (Cichlidae, Characidae and Pimelodidae), Shrips } \\
\text { (Macrobrachium sp.) \& Insects Odonata. }\end{array}$ & Santos et al. 2001 \\
\hline $\begin{array}{l}\text { Juturnaíba Reservoir } \\
\text { (Southeastern Brazil) }\end{array}$ & Non-native & $\begin{array}{l}\text { Fishes (Characidae, Clupeidae and Cichlidae, unidentifield fishes), Insects } \\
\text { (Odonata and Ephemeroptera) }\end{array}$ & This study \\
\hline
\end{tabular}


juvenile fishes and insects whereas the largest individuals feed mainly on fishes. It seems that the opportunism is a more favorable strategy, rather than the specialism for C. kelberi in the Juturnaíba Reservoir, as this fish reaches larger size.

Seasonally, there was an inverse relationship between stomach fullness and the niche breadth for C. kelberi in the Juturnaíba Reservoir. In summer, it was detected the lowest stomach fullness and the highest niche breadth, whereas the opposite was recorded in late spring. The greater contribution of Odonata during the winter and late spring may have contributed for the high stomach fullness and low niche breadth in this period. Seasonal changes in feeding activity have been reported for this species in other reservoirs, as the case of the Volta Grande Reservoir (Gomiero \& Braga 2004a) and the Leme Lake (Villares Junior \& Gomiero 2010), which are likely to be associated to the dynamic in environmental conditions that affect seasonal resources availability. Villares-Junior \& Gomiero (2010) reported that $C$. kelberi changes diet according to season, with low feeding activity during the winter when it feed on several fish species, increasing feeding activity during the spring, by preying mainly on Tilapia spp. and practicing cannibalism in summer/early autumn. In the present study, no significant seasonal differences were found in the diet composition of $C$. kelberi.

Piscivorous invaders change the diet composition in the new environment more than other trophic levels (Pereira et al. 2015), with direct effects on prey populations. In the case of C. kelberi, piscivory is the main feeding habit that have been recorded in several other studies (e.g., Santos et al. 2001, Rabelo et al. 2002, Gomiero \& Braga 2004a, Novaes et al. 2004, Santos et al. 2004, Villares-Junior \& Gomiero 2010, Pereira et al. 2015). It is expected that non-native species exploit the available resources in the new environment, and it was confirmed in this study, especially by the high consumption of Odonata and others invertebrates. We found that feeding plasticity is probably important to explain persistence of $C$. kelberi in reservoirs. Moreover, invasive species face new ecological interactions in the invaded environment and the success of an invasion might be affected by the biotic resistance presented by competitors and predators (Thompson et al. 2012).

The colonization and adaptation of Cichla spp. in altered environments such as reservoirs, is likely to result in decline of the original fish community. The presence of these highly adapted and quickly proliferating predators can cause serious losses to these communities by predation, competition, and cascade effects throughout the whole trophic chain. However, Cichla species attract recreational anglers, involving in this way the whole riverine community that depends on native fish species. The impact on the native ichthyofauna have been reported by several studies where there were introductions of species of Cichla (Pelicice \& Agostinho 2009, Menezes et al. 2012, Orsi \& Britton 2014). In the Juturnaíba Reservoir, C. kelberi seems to benefit from some native species (e.g., Astyanax spp. and P. platana). The opportunist feeding habit of $C$. kelberi enables to explore efficiently native species, thus facilitating its success to adapt and disperse in new colonized areas. A generalist feeding strategy, coupled with exceptionally high predatory ability may result in the proliferation of C. kelberi population.

\section{Acknowledgments}

We thank Dr. Gustavo Wilson Alves Nunan, PhD, in memoriam, of the Laboratory of Ichthyology, Museu Nacional, Universidade Federal do Rio de Janeiro. This work is was part of the doctoral thesis of the first author. Research was partially supported by CAPES-FAPERJ Program, Proc. number E-26-150.004/2007.

\section{Author Contributions}

Helaine da Silva Mendonça and Alexandre Clistenes de A. Santos: Substantial contribution in the concept and design of the study.

Helaine da Silva Mendonça and Alexandre Clistenes de A. Santos: Contribution to data collection.

Helaine da Silva Mendonça; Alexandre Clistenes A. Santos, Mariana Marques Martins e Francisco Gerson Araújo: Contribution to data analysis and interpretation.

Helaine da Silva Mendonça; Mariana Marques Martins and Francisco Gerson Araújo: Contribution to manuscript preparation.

Helaine da Silva Mendonça; Alexandre Clistenes de A. Santos and Francisco Gerson Araújo: Contribution to critical revision, adding intelectual content.

\section{Conflicts of interest}

The authors declare that they have no conflict of interest related to the publication of this manuscript.

\section{References}

ADAMS, C.E. 1991: Shift in pike, Esox lucius L., and predation pressure following the introduction of ruffe, Gymnocepahlus cermus, L., to Loch Lomond. J. Fish Biol. 38 (5): 663-667.

AFONSO, A.E.E. \& CUNHA S.O.B. 1989. Impacto sócio-ambiental da construção de uma barragem - Lagoa de Juturnaíba. Silva Jardim. RJ. Cad. Geoc. 3: 93-107.

AGOSTINHO A.A., PELICICE, F.M. \& GOMES, L.C. 2008. Dams and the fish fauna of the Neotropical region: impacts and management related to diversity and fisheries. Braz. J. Biol. 68 (4): 1119-1132.

ALBRECHT, M.P. \& CARAMASCHI, E.P. 2003. Feeding ecology of Leporinus friderici (Teleostei, Anostomidae) in the upper Tocantins River. Central Brazil before and after installation of a hydroelectric plant. Stud. Neotrop. Fauna Environ. 38(1): 33-40.

ANDERSON, M.J., GORLEY, R.N. \& CLARKE, K.R. 2008. Permanova + for Prime: Guide software and Statical methods. Plymouth: Primer-e Available at http://www.primer-e.com/permanova.htm.

ARAÚJO, E.S.E., MARQUES, I.S., FREITAS, A.L., NEUBERGER, R.F. \& PELICICE, F.M. 2013. Changes in distance decay relationships after river regulation: similarity among fish assemblages in a large Amazonian river. Ecol. Freshw. Fish 22: 543-552.

ARCIFA, M.S. \& MESCHIATTI, A.J. 1993. Distribution and feeding ecology of fishes in Brazilian Reservoir: Lake Monte Alegre. Interciência, 18: 302-313.

AZEVÊDO, M.C.C., CRUZ FILHO, A.G. \& ARAUJO, F.G. 2016. Use of a mangrove area in Southeastern Brazil by fishes: are there temporal changes in the structure of the community? Mar. Ecol. 37: 1223-1238.

BRAGA, F.M.S. 1990. Aspectos da reprodução e alimentação de peixes comuns em um trecho do rio Tocantins entre Imperatriz e Estreito. Estados do Maranhão e Tocantins, Brasil. Braz. J. Biol. 50: 547-558. 
BRANDNER, J., PANDER, J., MUELLER, M., CERWENKAA.F. \& GEIST, J. 2013. Effects of sampling techniques on population assessment of invasive round goby Neogobius melanostomus. J. Fish Biol. 82: 2063-2079.

CÂMARA, M.R., CHELlAPA, N.T., CHELlAPA, S. 2002. Ecologia reprodutiva do Cichla monoculus um ciclídeo amazônico no semi-árido do Rio Grande do Norte. Acta Limnol. Bras. 14 (2): 9-16.

CHELLAPA, S., CÂMARA, M.R., CHELLAPA, N.T., BEVERIDGE, M.C.M. \& HUNTINGFORD, F.A. 2003. Reproductive ecology of a neotropical cichlid fish Cichla monoculus (Osteichthyes: Cichlidae). Braz. J. Biol. 63(1): 17-26.

DURÃES, R., SANTOS, G.B. \& P.S. FORMAGIO. 2000. Observações sobre a alimentação do tucunaré Cichla monoculus (Pisces, Cichlidae) em um reservatório do sudeste brasileiro. Rev. Ictiol. 8 (1/2): 53-56.

FUGI, R., LUZ-AGOSTINHO, K.D.G. \& AGOSTINHO, A.A. 2008. Trophic interaction between an introduced (peacock bass) and a native (dogfish) piscivorous fish in a Neotropical impounded river. Hydrobiologia 607: 143-150.

GOMIERO, L.M. \& BRAGA, F.M.S. 2003. Relação peso-comprimento e fator de condição para Cichla cf. ocellaris e Cichla monoculus (Perciformes. Cichlidae) no reservatório de Volta Grande, Rio Grande - MG/SP. Acta Scient. Biol. Sci. 25(1): 79-86.

GOMIERO, L.M. \& BRAGA, F.M.S. 2004a. Feeding of introduced species of Cichla (Perciformes. Cichlidae) in Volta Grande Reservoir. River Grande (MG/SP). Braz. J. Biol. 64 (4):787-795.

GOMIERO, L.M.\& BRAGA, F.M.S. 2004b. Cannibalism as the main feeding behavior of tucunares introduced in Southeast Brazil. Braz. J. Biol. 64(3): 625-632.

GOMIERO, L.M., CARMASSI, A.L., RONDINELI, G.R., VILLARESJUNIOR, G.A. \& BRAGA, F.M.S. 2010. Growth and mortality of Cichla spp. (Perciformes, Cichlidae) introduced in Volta Grande Reservoir (Grande River) and in a small artificial lake in Southeastern Brazil. Braz. J. Biol. 10: 1093-1101.

GOZLAN, R. E. 2008. Introduction of non-native freshwater fish: Is it all bad? Fish Fisher, 9: 106-115.

HOEINGHAUS, D.J., AGOSTINHO, A.A., GOMES, L.C., PELICICE, F.M, OKADA, E.K., LATINI, J.D., KASHIWAQUI, E.A.L. \& WINEMILLER, K.O. 2009. Effects of river impoundment ecosystem services of large tropical rivers: embodied energy and market value of artisanal fisheries. Conserv. Biol. 23:1222-1231.

JEPSEN, D.B., WINEMILLER, K.O. \& TAPHORN, D.C. 1997. Temporal patterns of resource partitioning among Cichla species in a Venezuela blackwater river. J. Fish Biol. 51: 1085- 1108.

KATI S, MOZSÁR A., ÁRVA D., COZMA N.J., CZEGLÉDI I., ANTAL L., NAGY S.A. \& ERÖS T. 2015. Feeding ecology of the invasive Amur sleeper (Perccottus glenii Dybowski, 1877) in Central Europe. Int. Rev. Hydrobiol. 100 (3-4): 116-128.

KHAN, M.F. \& PANIKKAR P. 2009. Assessment of impacts of invasive fishes on the food web structure and ecosystem properties of a tropical reservoir in India. Ecol. Model. 220: 2281-2290.

KAWAKAMI, E. \& VAZZOLER, G. 1980. Método gráfico e estimativa de índice alimentar aplicado no estudo de alimentação de peixes. Bol. Inst. Oceanogr. 29(2): 205-207.

KOLAVENKO, K., DIBBLE, E. F., AGOSTINHO, A. A., CATANHÊDE, G. \& FUGI, R. 2010. Direct and indirect effects of an introduced piscivore, Cichla kelberi and their modification by aquatic plants. Hydrobiologia 638: 245-253

KULLANDER S.O. \& FERREIRA E.J.G. 2006. A review of the South American cichlid genus Cichla with descriptions of nine new species (Teleostei: Cichlidae). Ichthyol, Explor, Freshw, 17(4):289-398.

LATINI, A.O. \& PETRERE, M. 2004. Reduction of a native fish fauna by alien species: an example from Brazilian freshwater tropical lakes. Fisheries Manag. Ecol. 11: 71- 79.
LAXSON, C.L., MCPHEDRAN, K.N., MAKAREWICZ, J.C., TELESH, I. \& MACISAAC, H.J. 2003. Effects of the non-native cladoceran Cercopagis pengoi on the lower food web of Lake Ontario. Freshw. Biol. 48: 2094-2106.

LODGE, D. M. 1993: Biological invasions: Lessons for ecology. Trends Ecol. Evol. 8, 133-137.

LOWE-MCCONNEL, R.H. 1969. Speciation in tropical freshwater fishes. Biol. J. Linn. Soc. 1(1-2): 51-75.

MAGALHÃES, A.L.B., SATO, Y., RIZZO, E. FERREIRA, R.M.A. \& BAZZOLI, N. 1996. Ciclo reprodutivo do tucunaré Cichla ocellaris (Schneider. 1801) na represa de Três Marias. MG. Arq. Bras. Med. Vet. Zootec. 48(1): 85-92.

MARCHETTI, M.P. 1999. An experimental study of competition between the native Sacramento perch (Archoplites interruptus) and introduced bluegill (Lepomis macrochirus). Biol. Invasions 1: 55-65.

MEFFE G.K., CARROLL C.R. \& PIMM S.L. 1997: Community and ecosystem level conservation; species interactions, disturbance regimes and invading species. In: Meffe G.K., Carroll C.R. (eds.): Principles of Conservation Biology, Sunderland, Sinauer, p. 235-268.

MENEZES, R.F., ATTAYDE, J.L., LACEROT, G., KOSTEN, S., SOUZA, C. COSTA, L.S., VAN NES, E.H. \& JEPPSEN, E. 2012 Lower biodiversity of native fish but only marginally altered plankton biomass in tropical lakes hosting introduced piscivorous Cichla $\mathrm{cf}$. ocellaris. Biol Invasions 14:1353-1363.

MONTAÑA, C.G., LAYMAN, C.A. \& WINEMILLER, K.O. 2011. Gape size influences seasonal patterns of piscivore diets in three Neotropical rivers. Neotrop. Ichthyol. 9(3): 647-655.

NOVAES, J.L., CARAMASCHI, E.P. \& WINEMILLER, K.O. 2004. Feeding of Cichla monoculus Spix \& Agassiz, 1831 (Teleostei; Cichlidae) during and after reservoir formation in the Tocantins River. Central Brazil. Acta Limnol. Bras. 16(1): 41-49.

OLIVEIRA, S.L., MENDES, Z.C., CRISÓSTOMO, L.C. \& ARAÚJO, F.G. 1986. Resultados preliminares do levantamento ictiológico na represa de Ribeirão das Lajes, estado do Rio de Janeiro. Publ. Avuls. Mus. Nac. Rio de Janeiro 65: 87-90.

ORSI, M.L. \& BRITTON, J.R. 2014. Long-term changes in the fish assemblage of a neotropical hydroelectric reservoir. J. Fish Biol. 84 (6): 1964-1970.

PELICICE, F.M. \& AGOSTINHO, A.A. 2009. Fish fauna destruction after the introduction of a non-native predator (Cichla kelberi) in a Neotropical reservoir. Biol. Invasions 11: 1789-1801.

PELICICE, F.M., LATINI, J.D. \& AGOSTINHO, A.A. 2015. Fish fauna disassembly after the introduction of a voracious predator: main drivers and the role of the invader's demography. Hydrobiologia 746: 271-283.

PEREIRA, L.S., AGOSTINHO, A.A.M. \& GOMES, L.C. 2015. Eating the competitor: a mechanism of invasion. Hydrobiologia, 746: 223-231.

PINTO-COELHO, R.M., BEZERRA-NETO, J.F., MIRANDA, F., MOTA, T.G., RESCK, R., SANTOS, A.M., MAIA-BARBOSA, P.M., MELLO, N.A.S.T., MARQUES, M.M., CAMPOS, M.O. \& BARBOSA, F.A.R. 2008. The inverted trophic cascade in tropical plankton communities: Impacts of exotic fish in the Middle Rio Doce lake district, Minas Gerais, Brazil. Braz. J. Biol. 68 (4): 1025-1037

RABELO, H. \& ARAÚJO-LIMA, C.A.R.M. 2002. A dieta e o consumo diário de alimento de Cichla monoculus na Amazônia central. Acta Amazon. 32(4): 707-724.

RIBEIRO, F., ORJUELA, R.L., MAGALHÃES, M.F. \& COLLARES-PEREIRA M.J. 2007. Variability in feeding ecology of a South American cichlid: a reason for successful invasion in mediterranean-type rivers? Ecol. Freshw. Fish 16: 559-569. 
Mendonça, H.S. et al.

SANTOS, A.F., SANTOS, L.N. \& ARAÚJO, F.G. 2011. Digestive tract morphology of the neotropical piscivorous fish Cichla kelberi (Perciformes: Cichlidae) introduced into an oligotrophic Brazilian reservoir. Rev. Biol. Trop. 59(3): 1245-1255.

SANTOS, A.F.G.N, SANTOS, L.N., ANDRADE, C.C., SANTOS, R.N., ARAÚJO, F.G. 2004. Alimentação de duas espécies de peixes carnívoros no Reservatório de Lajes, RJ. Rev. Univ. Rural Série Ciências da Vida, Seropédica, RJ, EDUR, v. 24(1): 161-168

SANTOS, G.B., MAIA-BARBOSA, P.M., VIEIRA, F. \& LOLEZ, C.M. 1994. Fish and zooplankton community structure in reservoirs of southeastern Brazil: Effects of the introduction of exotic predatory fish. In PINTOCOELHO, RM., GIANI, A. \& SPERLING, EV. (Eds.). Ecology and Human Impact on Lakes and Reservoirs in Minas Gerais. Belo Horizonte: UFMG. p. $115-132$.

SANTOS, L.N.A., GONZALEZ, A.F. \& ARAÚJO, F.G. 2001. Dieta do tucunaréamarelo Cichla monoculus (Bloch \& Schneider) (Osteichthyes. Cichlidae) no Reservatório de Lajes. Rio de Janeiro. Brasil. Rev. Bras. Zool. 18 (1): 191-204.

SCHAFER, L.N., PLATELL, M.E., VALESINI, F.J. \& POTTER, I.C. 2002. Comparisons between the influence of habitat type, season and body size on the dietary compositions of fish species in nearshore marine waters. J. Exp. Mar. Biol. Ecol. 278:67-92.
THOMPSON, K.A., HILL, J.E. \& NICO, L.G. 2012. Eastern mosquitofish resists invasion by nonindigenous poeciliids through agonistic behaviors. Biol Invasions, 14: 1515-1529.

VILLARES-JUNIOR, G.A. \& GOMIERO, L.M. 2010. Feeding dynamics of Cichla kelberi Kullander \& Ferreira. 2006 introduced into an artificial lake in southeastern Brazil. Neotrop. Ichthyol. 8 (4):819-824,

VOLTERRA, V. 1928. Variations and fluctuations of the number of individuals in animal species living together. J. Conseil Inter. Explor. Mer 3: 3-51.

WINEMILLER, K.O. 2001. Ecology of peacock cichlids (Cichla spp.) in Venezuela. J. Aquaricult Aquat. Sci. 9: 93-112.

WINEMILLER, K. O., TAPHORN, D. C. \& BARBARINO-DUQUE, A. 1997. Ecology of Cichla (Cichlidae) in Two Blackwater Rivers of Southern Venezuela. Copeia, 1997: 690-696.

ZARET, T. M \& PAINE, R. T. 1973. Species introductions in a Tropical lake. Science, 482 (4111): 449-455.

ZAVALA-CAMIN, L.A. 1996. Introdução aos estudos sobre alimentação natural em peixes. EDUEM/Editora da Universidade Estadual de Maringá. Maringá (Paraná), Brasil.

ZAVALETA, E.S., HOBBS, R.J. \& MOONEY, H.A. 2001. Viewing invasive species removal in a whole-ecosystem contexto. Trends Ecol. Evol. 16: 454-459. 